\title{
Molecular Detection of Rabies Lyssaviruses from Dogs in Southeastern Nigeria: Evidence of TransboundaryTransmission of Rabies in West Africa
}

\author{
Ukamaka U Eze $^{1, *(1)}$, Ernest C Ngoepe ${ }^{2}$, Boniface M Anene ${ }^{1}$, Romanus C Ezeokonkwo ${ }^{3}$, \\ Chika I Nwosuh 4 (D) and Claude T Sabeta ${ }^{2,5}$ \\ 1 Department of Veterinary Medicine, Faculty of Veterinary Medicine, University of Nigeria, \\ Nsukka 410001, Nigeria; boniface.anene@unn.edu.ng \\ 2 Agricultural Research Council-Onderstepoort Veterinary Institute, OIE Rabies Reference Laboratory, \\ Onderstepoort 0110, South Africa; ngoepee@arc.agric.za (E.C.N.); SabetaC@arc.agric.za (C.T.S.) \\ 3 Department of Veterinary Parasitology and Entomology, Faculty of Veterinary Medicine, University of \\ Nigeria, Nsukka 41001, Nigeria; romanus.ezeokonkwo@unn.edu.ng \\ 4 National Veterinary Research Institute, Vom, Plateau State 930103, Nigeria; chikanwosuh@gmail.com \\ 5 Department of Veterinary Tropical Diseases, University of Pretoria, Onderstepoort 0110, South Africa \\ * Correspondence: ukamakauchenna.eze@unn.edu.ng
}

Received: 27 August 2019; Accepted: 24 September 2019; Published: 23 January 2020

\begin{abstract}
Despite being the first country to register confirmed cases of Mokola and Lagos bat lyssaviruses (two very distant lyssaviruses), knowledge gaps, particularly on the molecular epidemiology of lyssaviruses, still exist in Nigeria. A total of 278 specimens were collected from dogs in southeastern Nigeria between October 2015 and July 2016, and 23 (8.3\%) of these tested positive for lyssaviruses with the direct fluorescent antibody test (DFA). The lyssaviruses were genetically characterized by amplifying the highly conserved nucleoprotein $(\mathrm{N})$ gene of the rabies lyssaviruses (RABVs) of the viral genome. Phylogenetic analyses of the nucleotide sequences showed that all the RABV sequences in this study were of the Africa-2 lineage. Our results demonstrated that transboundary transmission of rabies lyssavirus is a key event, given that one of the RABV sequences (MN196576) clustered with rabies variants from neighboring Niger Republic. Furthermore, three RABVs from dogs from Anambra State clustered separately forming a novel and distinct group. Our results demonstrated that transboundary transmission of RABLVs is a key driver in the spread of rabies in West Africa. In order for the successful control of this zoonotic disease, a multinational stepwise surveillance and elimination of rabies in Africa by 2030 is probably the solution for regional elimination.
\end{abstract}

Keywords: rabies lyssavirus; dogs; molecular characterization; southeastern Nigeria; transboundary transmission

\section{Introduction}

Rabies is one of the oldest but deadliest zoonotic diseases known to man, and has a case fatality rate approaching $100 \%$ once clinical symptoms are apparent. The first report of the disease in Nigeria dates back to about 100 years ago, and since then rabies has been endemic in this West African country, resulting in approximately 1637 annual human deaths [1,2]. The causative agent of rabies is a highly neurotropic virus and member of the 16 currently recognized viral species of the Lyssavirus genus [3,4]. Apart from RABV, which is mainly dog-mediated through bites but also scratches, there are other lyssaviruses that were identified in the country in the late 1950s, namely Lagos bat lyssavirus (LBLV) and Mokolalyssavirus (MOKL), making this country an important place for lyssavirus origin and 
evolution [5,6]. These two, LBLV and MOKL, have not been identified since the late 1950s, underlining the lack of surveillance activities for these viruses.

Nigeria is a large country and a member of the 16 West African regional network, a region that covers a total land area of about 5,112,903 $\mathrm{km}^{2}$ [7], with an estimated population of about 381,981,000 as of 2017 [8]. The boundaries within the West African countries are porous (as in most parts of the African continent) and allow all sorts of activities such as smuggling, human, drug, and illicit arms trafficking, nomadism, and dog trading, which may promote rabies virus transmission $[9,10]$. The porosity of the border areas facilitates transboundary transmission of animal diseases such as rabies as vectors move easily between neighboring countries. The illegal trade of dogs within and across West African countries is a contributory factor to the transboundary movement of the disease, a phenomenonnot only unique to Africa [11-17]. In the sub-Saharan African region, three genetically distinct rabies lyssavirus lineages (Africa 1, 2, and 3) were identified, each spanning a different region [18]. Initially, African sub lineage $1 \mathrm{a}$ and lineage 2 occurred mainly in the West African countries [19]. However, further analyses showed that the rabies lyssavirus belonging to African lineage $1 \mathrm{~b}$, initially thought to be exclusively found in eastern, central, and southern Africa, now occurs in West Africa [13], highlighting the complexity of rabies epidemiology in the region. Furthermore, a rabies lyssavirus strain in Liberia was found to cluster with other rabies viruses in the China lineage 2, confirming transcontinental transmission of the disease [20].

The reverse-transcription polymerase chain reaction (RT-PCR), including the sequencing of specific gene products and reconstruction of phylogenetic trees, are now very important tools used in monitoring disease epidemiology and surveillance [21]. The rabies lyssaviruses from northern and western parts of Nigeria have been previously characterized [12,22-24], but only four rabies lyssaviruses from dogs were characterized from Enugu (Southeastern Nigerian) [25]. The scant molecular data available was ample motivation to genetically characterize additional rabies lyssaviruses from Southeastern Nigeria. Furthermore, rabies is a highly under-reported disease in the region, as many rabies cases are not presented to veterinary clinics and hospitals, and we therefore decided to survey the dog markets for possible rabies-infected dogs and assess the public health burden of the disease. The study was therefore designed to detect RABVs in dogs and determine the phylogenetic relationships of the rabies lyssaviruses from Southeastern Nigeria, neighboring countries (Cameroon, Chad, Niger, and Benin), and other regions by comparing the nucleoprotein gene nucleotide sequences.

\section{Materials and Methods}

\subsection{Ethical Approval}

The ethical approval (UNN/eTC/14/68625) for the molecular investigation of rabies lyssaviruses in southeastern Nigeria was granted by the University of Nigeria Ethical Committee on the 17th of August, 2015. The brain specimens were collected with the consent of dog traders, dog meat sellers, and pet owners.

\subsection{Study Locations}

The study was conducted in the Southeastern geopolitical zone of Nigeria, formerly known as the eastern region (Figure 1). Southeastern Nigeria, also known as Igboland (because the common language is Igbo language), is made up of five States, covering a total land area of $17,545 \mathrm{~km}^{2}$ with an estimated population of 40 million [26]. The region is located between latitudes $7^{\circ} 07^{\prime} \mathrm{N}$ and $3^{\circ} 90^{\prime} \mathrm{N}$, and longitudes $6^{\circ} 51^{\prime} \mathrm{E}$ and $8^{\circ} 30^{\prime} \mathrm{E}$. This area is characterized by a tropical climate with a distinct wet season that lasts from April to October, and a dry season that lasts from November to March, each year. Three (Anambra, Ebonyi, and Enugu) of the five States of the geopolitical zones were selected by random sampling and included in the study. The dog markets and restaurants in each of the States which are located in the rural areas were selected purposively based on availability of slaughtered dogs for human consumption, while the clinic location in urban area was based on presentation of 
suspected rabies cases. Given that there is currently no rabies diagnostic laboratory in Southeastern Nigeria, all the rabies specimens were sent to National Veterinary Research Institute (NVRI), Vom, Plateau State, which is the national rabies reference laboratory.

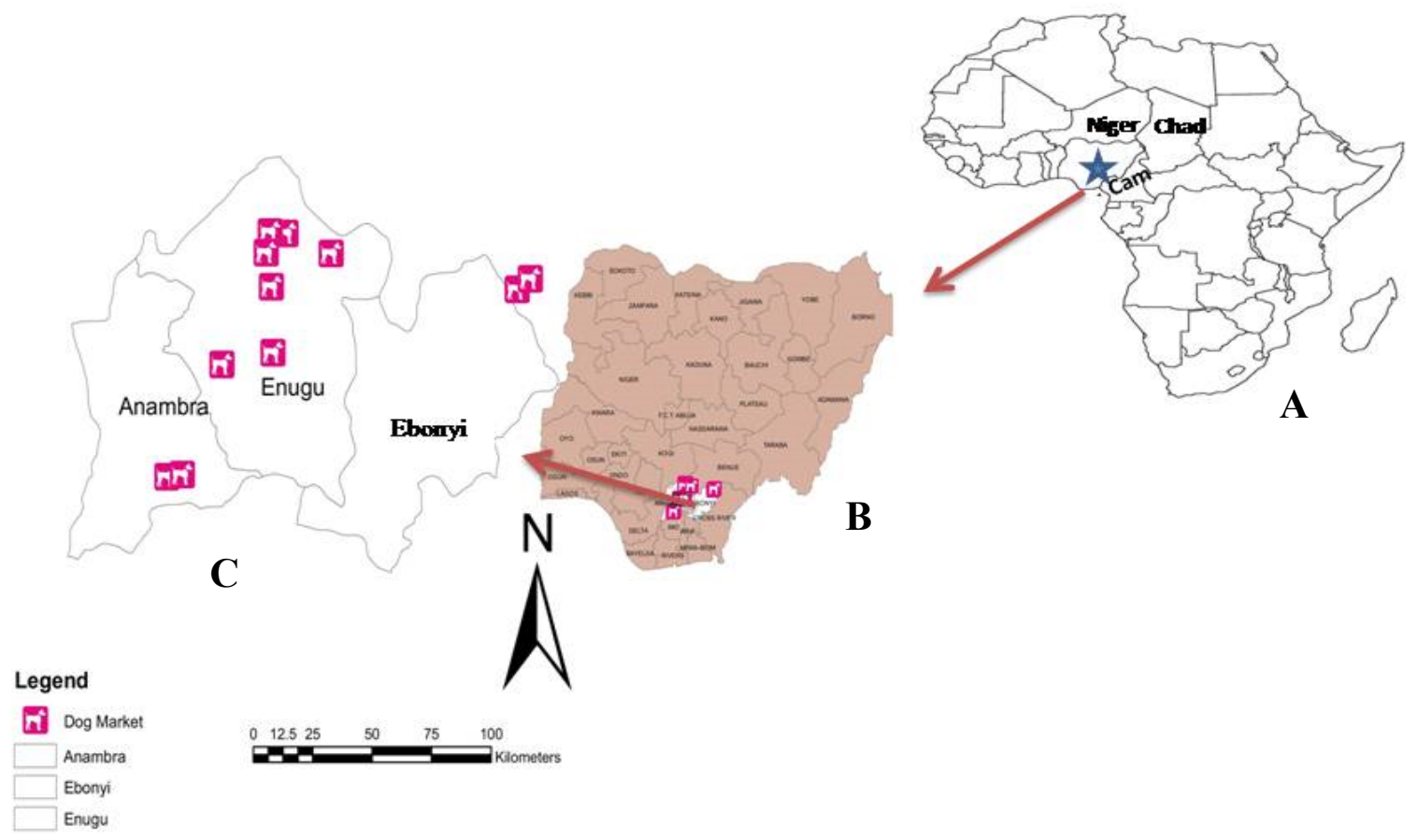

Figure 1. Map of West Africa showing Nigeria (A), South East region in the southeastern part of the country (B), and the five states of Southeastern Nigeria, showing areas of specimen collection in Anambra, Ebonyi, and Enugu States (C).

\subsection{Specimen Collection}

The specimens were collected over 9 months, between October 2015 and July 2016. During this period, a total of 278 dog heads were collected from dog markets, restaurants, and veterinary clinics. All the dog heads were transported to the postmortem room, Department of Veterinary Pathology and Microbiology, University of Nigeria, Nsukka. The composite brain parts (comprising the hippocampus, brain stem, cerebellum, and cerebrum) were extracted and stored in leak-proof containers. All the samples were stored frozen at $\left(-20^{\circ} \mathrm{C}\right)$ until analyzed.

\subsection{Direct Fluorescent Antibody Test for Detection of Rabies Lyssavirus Antigen}

The brain specimens were initially transported to the National Veterinary Research Institute, Vom (NVRI) at $4{ }^{\circ} \mathrm{C}$ for initial rabies diagnosis using the direct fluorescent antibody test (DFA) [27] using a fluorescein isothiocyanate (FITC) anti-rabies nucleocapsid conjugate (Fujirebio ${ }^{\circledR}$; Tokyo, Japan) as a stain. The DFA-positive brain specimens were then transported on ice packs to OIE Rabies Reference Laboratory at Onderstepoort (South Africa), where DFA was repeated using FITC anti-rabies nucleocapsid conjugate (BIORAD $\left.{ }^{\circledR} ; \mathrm{CA}, \mathrm{USA}\right)$.

Out of the 278 brain tissue specimens, 23 (8.3\%) were positive for rabies lyssaviruses.

\subsection{RNA Extraction}

One gram of each brain-infected tissue and a wild dog (Lycaonpictus) brain tissue (ReferenceLaboratory\#811/97) previously shown to be RABV positive (and of the canid rabies biotype) were homogenized in sterile Eppendorf tubes. Total viral RNA was extracted using Tri Reagent (Sigma Aldrich, USA) according to the manufacturer's instructions. The concentrations of the viral RNAs 
were measured using a NanoDrop spectrophotometer (NanoDrop Technologies; DE, USA) and stored at $-70^{\circ} \mathrm{C}$ until required for further analysis.

\subsection{Detection of Nucleoprotein (N) Gene of Lyssaviruses Using Reverse Transcription Polymerase Chain} Reaction (RT-PCR)

A combination of oligonucleotide primers, JW12 $55-74(+)$ and $304_{1514-1533}(-)$ and 550B $647-666(-)$ and Lys001 $15(+)$, were used in this study, Table $1[28,29]$ to target the full length or partial region of the $\mathrm{N}$ gene. The annealing positions and numbering of the oligos are based on that of Pasteur virus (PV) genome [30]. The primers were synthesized by Invitrogen Life Technologies (CA, USA), reconstituted with $10 \mathrm{mM}$ Tris- $\mathrm{HCl}$ (pH 8.0) and $100 \mathrm{mM}$ EDTA (TE) buffer (Promega; WI, USA), and stored frozen until utilized. The amplification of the $\mathrm{N}$ gene was performed using the GeneAmp ${ }^{\circledR}$ 9700 (Applied Biosystems; MA, USA).

Table 1. The Oligonucleotide primer sequences used in the study showing the annealing positions and their nucleotide sequences [28].

\begin{tabular}{|c|c|c|c|}
\hline Oligonucleotide Sense & Nucleotide Sequence $5^{\prime}-3^{\prime}$ & Uses & Position on Genome \\
\hline JW12 (+) & ATGTAACACC(C/T)CTACAATTG & $\begin{array}{l}\text { cDNA synthesis, PCR, } \\
\text { hnPCR }\end{array}$ & $55-74$ \\
\hline 001lys (+) & ACGCTTAACGAMAAA & cDNA synthesis & $1-15$ \\
\hline $304(-)$ & TTGACAAAGATCTTGCTCAT & PCR and sequencing & $1514-1533$ \\
\hline $550 \mathrm{~B}(-)$ & GTRCTCCARTTAGCRCACAT & hnPCR & $647-666$ \\
\hline
\end{tabular}

\subsection{Reverse Transcription (RT)}

Reverse transcription was done according to the protocol described by Markotter et al. [29]. Approximately $1 \mu \mathrm{g}$ of the total viral RNA was heat-denatured at $65{ }^{\circ} \mathrm{C}$ for $5 \mathrm{~min}$ and annealed with $2 \mathrm{pmol} / \mu \mathrm{L}$ of JW12 and lys+, and then immediately snap cooled on ice. This was immediately followed by reverse transcription performed at $45^{\circ} \mathrm{C}$ for $45 \mathrm{~min}$ in a $20 \mu \mathrm{L}$ reaction containing 200 units of Murine Moloney Leukemia Virus Reverse Transcriptase (Invitrogen; CA, USA), 40 units of Riboblock ${ }^{\circledR}$ ribonuclease inhibitor (ThermoScientific; MA, USA), $10 \mathrm{mM}$ of deoxynucleoside triphosphate (dNTP) mixture (Qiagen; Venlo, Netherlands), $0.1 \mathrm{M}$ dithithreitol (DTT), and 5× M-MLV reaction buffer (Invitrogen; CA, USA). At the end of the reverse transcription reaction, the cDNA was inactivated at $85^{\circ} \mathrm{C}$ for $5 \mathrm{~min}$, snap cooled for $1 \mathrm{~min}$, and then diluted two-fold with sterile nuclease free water and stored at $-20^{\circ} \mathrm{C}$ until required for use.

\subsection{Polymerase Chain Reaction (PCR) Assay}

The initial amplification of all the cDNA was performed using the primers JW12 (+) and 304 (-), targeting the full-length $\mathrm{N}$ gene [28]. An RNA sample extracted from a known rabies-positive sample of the canid variant of the RABV (an isolate from an African wild dog, Lycaonpictus, laboratory reference\#: 811/97) was included as a positive control. Briefly, a $50 \mu \mathrm{L}$ reaction mixture containing $2 \mu \mathrm{L}$ of the cDNA, 1.25 units of Takara Taq DNA polymerase (Takara Biotechnology; Shiga, Japan), $1.5 \mathrm{mM}$ $\mathrm{MgCl}_{2}, 10 \mathrm{mM}$ dNTP mixture, 40 pmol each of JW12 (+) and 304 (-), 1× Taq polymerase reaction buffer, and made up to $50 \mu \mathrm{L}$ with nuclease free water. The amplification was carried out on an ABI 9700 thermocycler (Applied Biosystems; MA, USA), with an initial denaturation at $94{ }^{\circ} \mathrm{C}$ for $2 \mathrm{~min}$, followed by 35 cycles of $\left[94^{\circ} \mathrm{C}\right.$ for $30 \mathrm{~s}, 50{ }^{\circ} \mathrm{C}$ for $30 \mathrm{~s}, 72{ }^{\circ} \mathrm{C}$ for $120 \mathrm{~s}$ ] and a final extension at $72{ }^{\circ} \mathrm{C}$ for $10 \mathrm{~min}$. Those samples that did not amplify in the first round were subjected to hemi-nested PCR targeting a partial region of the N-terminal region of the $\mathrm{N}$ gene. This was achieved by using the same conditions as described above, except that a 1:500 dilution of first round PCR was used as the template and 40 pmoles of 550B (-) as the reverse primer. Avoidance of false-positive PCR results was done following standard precautionary measures [31]. 


\subsection{Electrophoresis and Gel Image Documentation}

The amplicons were visualized under UV transillumination after electrophoresis at 100 volts for 45 min through $1 \%$ ethidium bromide stained agarose gels (Labnet, Power Station 300, USA), with a $100 \mathrm{bp}$ DNA ladder as the molecular weight marker (Promega, USA).

\subsection{PCR Product Purification and Sequencing}

The PCR products were purified using spin columns, (QIAquick ${ }^{\circledR}$ PCR Purification kit, Netherlands) according to the manufacturer's guidelines, and cycle sequenced bidirectionally. Analysis of the sequencing products was performed on an automated ABI 3100 DNA analyzer.

\subsection{Phylogenetic Analysis}

A consensus sequence of each RABV was obtained after the alignment of the forward and reverse sequences using algorithms in BioEdit [32]. Consensus sequences were trimmed to $1350 \mathrm{bp}$ and $400 \mathrm{bp}$ for the full and partial $\mathrm{N}$ regions, respectively. Multiple sequence alignment of the edited $\mathrm{N}$ region was performed using ClustalW [33]. Data analyses were conducted using Molecular Evolutionary Genetics Software Version 7 (MEGA7) [34]. The Kimura's two parameter model was used to calculate the genetic distances between pairs of sequences [35]. The results were used to construct a maximum likelihood tree using MEGA7. Bootstrapping of a 1000 replicates was used to statistically evaluate the branching order of the phylogenetic tree. Bootstrap support of $70 \%$ was considered significant and provided evidence for phylogenetic grouping [36]. Partial N nucleotide sequences of lyssaviruses from this study, representative rabies viruses from other part of Nigeria, neighboring countries, Africa, and other continents (GenBank) were included in the analysis (Table 2). The phylogenetic tree was rooted using Lagos Bat lyssavirus and other distant rabies related lyssaviruses. 
Table 2. Rabies diagnostic samples collected from Genbank for molecular and phylogenetic analysis.

\begin{tabular}{|c|c|c|c|c|}
\hline $\begin{array}{c}\text { Genbank Accession } \\
\text { Number }\end{array}$ & Year of Collection & Country & Host Species & Lineage \\
\hline MK144831 & 2014 & Taraba, Nigeria & Dog & Africa 2 \\
\hline KX874612 & 2010 & Jos, Nigeria & Dog & Africa 2 \\
\hline KX874613 & 2010 & Jos, Nigeria & Dog & Africa 2 \\
\hline КС 876040 & 2012 & Bauchi, Nigeria & Cattle & Africa 2 \\
\hline KJ 921998 & 2012 & Enugu, Nigeria & Dog & Africa 2 \\
\hline EU514571 & 2007 & Niger & Dog & Africa 2 \\
\hline EU514574 & 2007 & Niger & Dog & Africa 2 \\
\hline EU853648 & 1990 & Niger & Dog & Africa 2 \\
\hline EU718783 & 2006 & Chad & Dog & Africa 2 \\
\hline EU718735 & 2006 & Chad & Dog & Africa 2 \\
\hline KP976130 & 2007 & Mali & Canis lupus familiaris & Africa 2 \\
\hline КР976129 & 2007 & Mali & Canis lupus familiaris & Africa 2 \\
\hline AY103008 & 1996 & Nigeria & Human & Africa 2 \\
\hline U22636 & 1995 & Cameroon & Dog & Africa 2 \\
\hline U22635 & 1995 & Cameroon & Dog & Africa 2 \\
\hline U22485 & 1995 & Benin & Dog & Africa 2 \\
\hline DQ837463 & 1999 & Egypt & Dog & Africa 4 \\
\hline HG764581 & 2013 & Egypt & Cattle & Africa 4 \\
\hline HM368162 & 2007 & Ghana & Dog & Africa 1A \\
\hline HM368096 & 2008 & Ghana & Dog & Africa $1 \mathrm{~A}$ \\
\hline AY062090 & 2001 & Morocco & Fox & Africa 1B \\
\hline FJ947032 & 2009 & Ethiopia & Dog & Africa 1A \\
\hline GU062189 & 2009 & Ethiopia & Canissimensis & Africa 1A \\
\hline AY091627 & 2002 & Estonia & Raccoon dog & Europe \\
\hline KJ201902 & 2010 & India & Musmusculus & Asia \\
\hline FJ228535 & 1950 & USA & Dog & America \\
\hline JF747614 & 2008 & South Africa & Canine & Africa 3 \\
\hline KT892010 & 1997 & South Africa & African wild dog & Africa3 \\
\hline DQ194892 & 1997 & South Africa & African wild dog & Africa 3 \\
\hline DQ 866120 & 2006 & South China & Dog & Asia (China) \\
\hline AB981677 & 2012 & Laos & Canis lupus familiaris & Asia \\
\hline EU159399 & 1994 & China & Dog & Asia \\
\hline AB094438 & 2002 & Kyrgyzstan & Myotisblythii & Aravanlyssairus (Outgroup) \\
\hline DQ676932 & 2006 & South Africa & Human & Duvenhagelyssavirus (Outgroup) \\
\hline AY062073 & 2002 & South Africa & Bat & Lagos bat Lyssavirus (Outgroup) \\
\hline AY062074 & 2001 & Nigeria & Shrew & Mokolalyssavirus (Outgroup) \\
\hline
\end{tabular}

\section{Results}

\subsection{Quality of the Extracted RNA}

The purity ratio (quality) $(260 / 280 \mathrm{~nm})$ and concentration $(\mathrm{ng} / \mu \mathrm{L})$ of the extracted RNA showed that 19 RNA samples were between $1.6-1.8 \mathrm{~nm}$ and $1272.5-3538.5 \mathrm{ng} / \mu \mathrm{L}$, respectively. However, three $(14 \mathrm{NG}, 4 \mathrm{NG}$, and $6 \mathrm{NG})$ had purity ratios and nucleic acid concentration of $1.5(710 \mathrm{ng} / \mu \mathrm{L}), 1.4(432$ $\mathrm{ng} / \mu \mathrm{L})$, and $1.5(428 \mathrm{ng} / \mu \mathrm{L})$. Only a single sample (2NG) had a purity ratio of 1.3 and nucleic acid concentration of $342 \mathrm{ng} / \mu \mathrm{L}$.

\subsection{Gel Electrophoresis Result}

Twenty-two (96\%) of the 23 specimens (brain specimens from slaughtered dogs, $n=21$ and dogs presented to clinics as rabies-suspect, $n=2$ ) tested yielded high-quality amplicons of the expected size of the $\mathrm{N}$ gene region analyzed. Of the 22, twelve specimens successfully amplified the full $\mathrm{N}$ and the rest $(n=10)$ amplified in the hemi-nested PCR.

\subsection{Nucleoprotein Gene Features}

The consensus sequences were deposited in GenBank, and were assigned accession numbers (Table 3). 
Table 3. Rabies specimens collected from brain tissues of dogs (Canisfamiliaris) in Southeastern Nigeria for molecular and phylogenetic analysis.

\begin{tabular}{ccccc}
\hline S/N & Lab ID & Date of Collection & Source Location & Accession Number \\
\hline 1 & 14NG & 11 October 2015 & OrieOrba, Enugu State, Nigeria & MN196558 \\
2 & 11NG & 26 October 2015 & OrieOrba, Enugu State, Nigeria & MN196559 \\
3 & 18NG & 7 November 2015 & OrieOrba, Enugu State, Nigeria & MN196560 \\
4 & 12NG & 7 November 2015 & OrieOrba, Enugu State Nigeria & MN196561 \\
5 & 7NG & 6 December 2015 & OrieOrba, Enugu State Nigeria & MN196562 \\
6 & 17NG & 10 December 2015 & OrieOrba, Enugu State Nigeria & MN196563 \\
7 & 1NG & 19 December 2015 & OrieOrba, Enugu State Nigeria & MN196564 \\
8 & 20NG & 9 January 2016 & NkwoOgbede Enugu State, Nigeria & MN196565 \\
9 & 26NG & 10 January 206 & IheNze, Enugu State, Nigeria & MN196566 \\
10 & 28NG & 17 January 2016 & IheNze, Enugu State, Nigeria & MN196567 \\
11 & 29NG & 22 February 2016 & Umuna, Enugu State, Nigeria & MN196568 \\
12 & 23NG & 18 April 2016 & Iboko, Ebonyi State, Nigeria & MN196569 \\
13 & 13NG & 28 April 2016 & Nkwoogbede, Enugu State & MN196570 \\
14 & 19NG & 16 May 2016 & OrieOrba, Enugu State Nigeria & MN196571 \\
15 & 22NG & 16 May 2016 & OrieOrba, Enugu State Nigeria & MN196572 \\
16 & 21NG & 29 May 2016 & NkwoIgboukwuAnambra State, Nigeria & MN196573 \\
17 & 27NG & 7 June 2016 & NkwoIgboukwuAnambra State, Nigeria & MN196574 \\
18 & 25NG & 7 June 2016 & NkwoIgboukwuAnambra State, Nigeria & MN196575 \\
19 & 16NG & 20 July 2016 & Vet Clinic Uwani Enugu, Nigeria & MN196576 \\
\hline
\end{tabular}

All the nucleotide sequences obtained in this study belong to Africa 2 lineage. The topology of the phylogenetic trees for both nucleotide and amino acid sequences were similar (Figures 2 and 3 ). A nucleotide sequence identity of $97.3 \%$ of the RABVs was obtained for this panel of viruses from dogs from Southeastern Nigeria and those from other parts of the country. Similarly, $97 \%$ amino acid sequence identity was observed between rabies viruses from Southeastern Nigeria and elsewhere in the country. The majority of the taxa ( 15 of the 19) clustered with RABV variants from the Plateau, Taraba, and Bauchi states. Of the 19 RABV nucleotide sequences obtained from this study, 15 were from Enugu State, and this is probably because of the existence of the largest dog market (OrieOrba) located in the State, and therefore more specimens were generally collected from there. A virus recovered from Enugu State (MN196576) clustered with lyssaviruses from the Niger Republic, and the node for this cluster was supported by a statistically significant bootstrap support value of $90 \%$. Three viruses from dogs from Anambra State, MN196573, MN19573, and MN19574 formed a sub-cluster, albeit with a low bootstrap support value of $34 \%$. However, this was no surprise, as these lyssaviruses originated from the same source location, thereby forming a sub-cluster (Figure 2). 


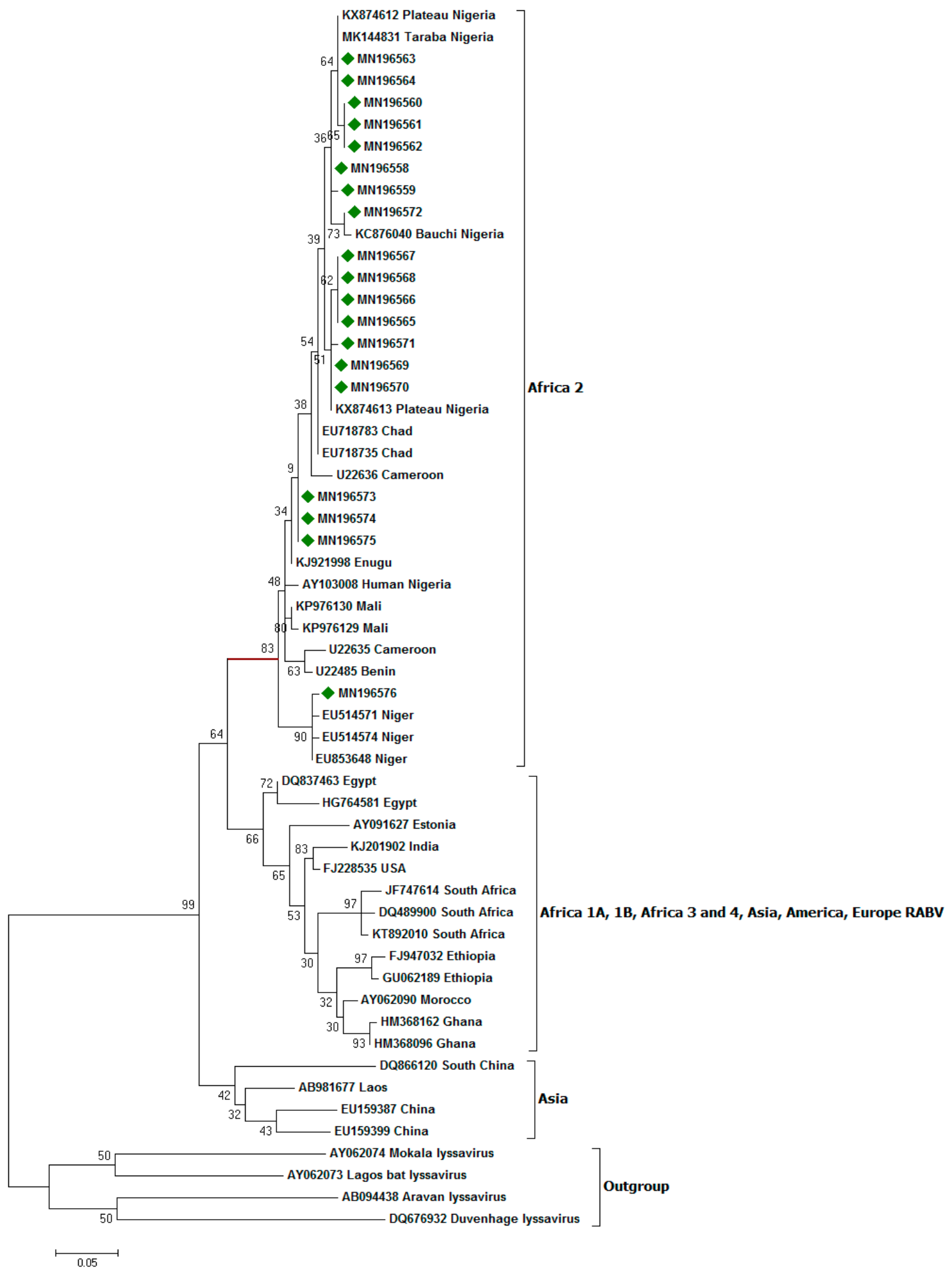

Figure 2. Maximum likelihood (ML) phylogenetic tree of the 19 Southeastern Nigerian RABV N-genes generated using ML algorithm (1000 bootstrap replications). The analyses involved 56 nucleotide sequences. All positions with $<95 \%$ site coverage were eliminated. Evolutionary analyses were conducted in MEGA7 [34]. The bootstrap values (\%) are shown on the nodes supporting these branches. The tree is drawn to scale, with branch lengths in the same units as those of the evolutionary distances used to infer the phylogenetic tree. The evolutionary distances were computed using the Kimura two-parameter method [37] and are in the units of the number of base substitutions per site. Isolates for which the partial $\mathrm{N}$ gene sequence was obtained in this study are indicated by a diamond green color. 


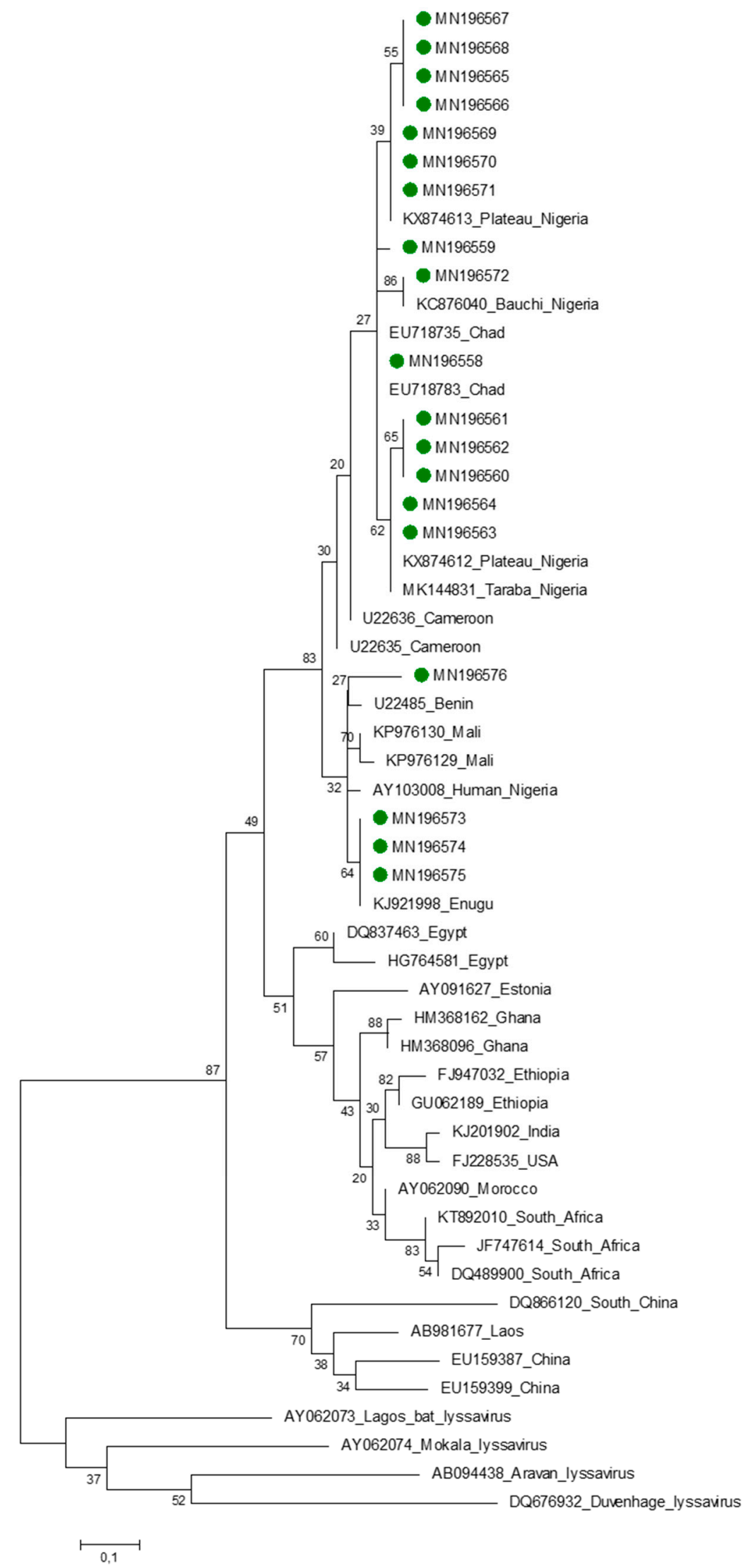

Figure 3. Maximum likelihood (ML) phylogenetic tree of the 19 Southeastern Nigerian RABV nucleoprotein deduced amino acid sequences generated using ML algorithm (1000 bootstrap replications). 


\section{Discussion}

This study was undertaken with a view to detecting and genetically characterizing RABVs circulating among dogs in Southeastern Nigeria from the dog markets and other rabies-suspect dogs presented at the Veterinary Clinic. The RABV nucleotide sequences generated and deposited in the NCBI GenBank were dog RABVs from the three States of Southeastern Nigeria, namely; Anambra, Ebonyi, Enugu. Apart from Enugu State, where 4 RABV isolates have been sequenced and deposited in GenBank [25], this is the first comprehensive molecular analysis of RABVs from this region.

The phylogenetic analysis showed that the RABV nucleotide sequences obtained in this study all belong to Africa linage-2 $[19,38]$ and are part of the greater rabies epidemiological cycle of the West African region. The data underscore the public health significance of rabies in this part of Africa, but within a unique set up of dog markets in Nigeria. The hazards should therefore be made known to the public, particularly the animal handlers or butchers, as there could be possible transmission from infected dogs to them. To date, there are no comprehensive reports of rabies in dog markets, and therefore this aspect of rabies epidemiology in rural Southeastern Nigeria will not be comprehensively known.

A detailed analysis of the phylogeographical structure of the Africa lineage- 2 revealed strong population subdivisions at the country level, with only limited virus transmission among localities. RABV variants from Central and North Africa clustered into Africa 1a and 4 lineages, whereas those from the southern African countries were in Africa $1 \mathrm{~b}$ and 3 clades. Clearly, all the RABV variants in this study were homogenous and closely related ( $99 \%$ sequence homology), suggesting the sharing of a common origin distinct to the outgroup. These data are consistent with the findings of Ogo et al. [12] who observed $99 \%$ nucleotide similarity amongst a panel of rabies viruses from Nigeria. This observation further supports the belief that rabies viruses from dogs in Nigeria belong to a single genetic lineage and a single major variant is maintained in this host species, albeit the low bootstrap values obtained. Ogunkoya et al. [39] demonstrated an identical pattern of reactivity amongst some Nigerian street rabies viruses recovered from domestic dogs from different geographical areas, suggesting antigenic homogeneity amongst the rabies viruses using monoclonal antibody (Mab) typing. This is also consistent with similar findings in other parts of the world, where identical reactivity patterns of rabies viruses were recovered from terrestrial species in contrast to the rabies viruses recovered from bats $[40,41]$. In southern Africa, a unique situation exists and different patterns of reactivity were observed between the canid and the mongoose rabies biotypes of southern Africa [42-45] also confirmed this observation with the antigenic analysis of rabies and rabies-related Mokola viruses from Zimbabwe. Nonetheless, molecular analyses provide a much finer delineation of pathogens, including rabies than antigenic typing.

The presence of smaller clades in the large cluster of viruses could indicate possible local outbreaks [42]. However, some of the variants from the same locality tend to group together, which could be attributed to a single and local rabies virus variant in that specific geographic zone. The site and geographic distribution patterns observed in this study could be attributed to the procurement and transportation of dogs from different parts of the country into dog markets in Southeastern Nigeria, thus promoting in-country rabies transmission.

The three viruses from IgboukwuAnambara state (MN196733, MN196574, and MN196575) formed a cluster and could be considered as a novel group, as this has not been observed previously. A RABV sequence (MN196576) obtained from a dog from Enugu State formed a cluster with nucleotide sequences from Niger Republic, with a bootstrap support of $90 \%$. The phylogenetic evidence gathered in this study suggests that the RABV variant (MN196576) could have originated in Niger, and may have been introduced into Southeastern Nigeria through unrestricted movement of animals mediated by humans across the porous border and illegal importation of dogs involved in dog trade from the neighboring countries $[11,46]$. This further demonstrate show long-distance transmission of rabies is facilitated by human mediated animal movements $[47,48]$. This observation is not limited to Nigeria, as a RABV from Benin (U22485) clustered with one RABV from Cameroon (U22635); also Ghana 
RABVs (HM368162 and HM368096) clustered with Moroccan RABV (AY062090). Recently, a molecular study of rabies in Liberia demonstrated that rabies lyssaviruses from this country clustered with China lineage-2, indicating transcontinental transmission of rabies [20].

Three specimens (14NG, $4 \mathrm{NG}$, and $6 \mathrm{NG}$ ), although they tested positive with the DFA and also yielded amplicons of desired band size (606 bp), the resulting nucleotide sequence data was poor, underscoring the difficulty that routine rabies diagnostic laboratories may face when applying such advanced tests for rabies diagnosis. The one specimen (2NG) that was DFA positive but yielded no positive result following RT-PCR could be considered false positive, an occurrence that may result in the distortion of accurate burden of the disease on the continent. This is highly likely since specimens for rabies diagnosis reach the diagnostic laboratories in a state that may compromise testing due the specimen condition.

\section{Conclusions}

This study has provided an enhanced understanding of the molecular epidemiology of rabies in Southeastern Nigeria, and provided a baseline of the epidemiology and transmission dynamics of dog rabies in Nigeria. Some of rabies viruses from Nigeria that clustered with others from the Niger Republic underscore the transboundary transmission of rabies mediated by human movement between neighboring countries. These activities, whilst against the law, could also have serious public health concerns as zoonotic and transboundary diseases may be easily spread through such practices. The findings here probably suggest a multinational approach to control rabies as driven by Pan American Health Organization (PAHO) in South America, and only then is elimination of dog rabies on the continent towards 2030 a reality. Moreover, the results of this study have shown the presence of a novel rabies variant in Southeastern Nigeria, and also that all the rabies lyssaviruses sequenced in this study all belong to the Africa 2 lineage and are very closely related, indicating a common origin. Hence, national diagnostic laboratories should continually type positive rabies cases in order to understand the diversity of lyssavirus variants involved in rabies epizootiology in this region.

Author Contributions: Conceptualization, U.U.E. and C.T.S.; Data curation, U.U.E.; Formal analysis, E.I.N. and U.U.E.; Funding acquisition, U.U.E., B.M.A., and C.T.S.; Investigation, U.U.E., E.C.N., B.M.A., R.C.E., C.I.N., C.T.S.; Methodology, U.U.E., E.C.N., C.I.N, C.T.S; Project administration, R.C.E., B.M.A., C.I.N., C.T.S.; Resources, U.U.E., and C.T.S.; Supervision, R.C.E., B.M.A., C.T.S.; Validation, E.C.N., C.I.N., C.T.S.; Visualization, U.U.E. and C.T.S.; Writing—original draft, U.U.E.; Writing—review and editing, U.U.E., E.C.N., B.M.A., R.C.E., C.I.N., C.T.S. All authors have read and agreed to the published version of the manuscript.

Funding: This research was partly funded by the Tertiary Educational Trust Fund (TETFund) of the Nigerian government through University of Nigeria IBR and Bench Space Intervention (TETFUND/DESS/UNI/NSUKKA/RP/VOL.V) and also the ARC-OVI National Assets [P10000029] Onderstepoort Veterinary Institute, South Africa.

Acknowledgments: The authors would like to thank the Tertiary Educational Trust Fund (TETFund) and ARC-OVI National Assets Onderstepoort Veterinary Institute, South Africa for their financial support; to the staff of department of veterinary medicine Laboratory, Rabies Unit National research Institute Vom, Rabie Unit, OIE reference laboratory, Onderstepoort Veterinary Institute, South Africa structural support to accomplish all lab analysis.

Conflicts of Interest: The authors declare no conflict of interest. The funders had no role in the design of the study; in the collection, analyses, or interpretation of data; in the writing of the manuscript, or in the decision to publish the results.

\section{References}

1. Umoh, J.U.; Belino, E.D. Rabiesin Nigeria: Ahistorical review. Int. J. Zoonosis 1978, 6, 41-48.

2. Hampson, K.; Coudeville, L.; Lembo, T.; Sambo, M.; Kieffer, A.; Attlan, M.; Barrat, J.; Blanton, J.D.; Briggs, D.J.; Cleaveland, S.; et al. Estimating the global burden of endemic canine rabies. PLoS Negl. Trop. Dis. 2015, 9, e0003709.

3. Fooks, A.R. Investigation of a human case of rabies in the United Kingdom. J. Clin. Virol. 2002, 25, 351-356. 
4. International Committeeon Taxonomy of Viruses (ICTV). Online 2018b Release EC50, Washington, DC.10th Report of the International Committee on Taxonomy of Viruses. 2018. Available online: http://www. ictvonline.org/virusTaxonomy.asp (accessed on 19 May 2019).

5. Kemp, G.E.; Causey, O.R.; Moore, D.L.; Odeola, A.; Fabiyi, A. Mokola Virus. Further studies on IbAn 27377, a new etiologic agent of zoonosis in Nigeria. Am. J. Trop. Med. Hyg. 1972, 21, 356-359. [CrossRef] [PubMed]

6. Kemp, G.E.; Moore, D.L.; Isoun, T.T.; Fabiyi, A. Mokola virus: Experimental infection and transmission studies with the shrew, a natural host. Arch. Virusforsch. 1973, 43, 242-250. [CrossRef] [PubMed]

7. USAID. Strategic Review, Feed the Future, United States Agency for International Development/West Africa. 2010. Available online: http://feedthefuture.gov/resource/feed-future-guide (accessed on 6 April 2019).

8. United Nations Department of Economic and Social Affairs (UNDES), Population Division. World Population Prospects: The 2017 Revision, Custom Data Acquired via Website; UNDES: New York, NY, USA, 2017.

9. Silberfein, M.; Conteh, A.H. Boundaries and Conflict in the Mano River Region of West Africa. Confl. Manag. Peace Sci. 2006, 23, 343-361. [CrossRef]

10. Sunday, O.V.O.; Okechukwu, O.; Okechukwu, R. Cross Border Crimes in West African Sub-Region: Implications for Nigeria's National Security and External Relations. Glob. J. Hum. Soc. Sci. F Political Sci. 2014, 14, 45-57.

11. Ogunkoya, A.B. Review of rabies and problems of rabies in Nigeria. In Proceedings of the National Conference/Work on Rabies; Ahmadu Bello University: Zaria, Nigeria, 2008; pp. 62-70.

12. Ogo, M.F.; Nel, L.; Sabeta, C.T. Phylogenetic Evidence of the Public and Veterinary Health Threat of Dog Rabies in Nigeria. Niger. Vet. J. 2011, 32, 40-44. [CrossRef]

13. Hayman, D.T.S.; Johnson, N.; Horton, D.L.; Hedge, J.; Wakeley, P.R.; Banyard, A.C.; Zhang, S.; Alhassan, A.; Fooks, A.R. Evolutionary History of Rabies in Ghana. PLoS Negl. Trop. Dis. 2011, 5, e1001. [CrossRef]

14. Nadin-Davis, S.A.; Turner, G.; Paul, J.P.V.; Madhusudana, S.N.; Wandeler, A.I. Emergence of Arctic-like Rabies Lineage in India. Emerg. Infect. Dis. J. 2007, 31, 111-116. [CrossRef]

15. Hyun, B.H.; Lee, K.K.; Kim, I.J.; Lee, K.W.; Park, H.J.; Lee, O.S. Molecular epidemiology of rabies virus isolates from South Korea. Virus Res. 2005, 114, 113-125. [CrossRef] [PubMed]

16. Kuzmin, I.V.; Botvinkin, A.D.; McElhinney, L.M.; Smith, J.S.; Orciari, L.A.; Hughes, G.J. Molecular epidemiology of terrestrial rabies in the former Soviet Union. J. Wildl. Dis. 2004, 40, 617-631. [CrossRef] [PubMed]

17. Mansfield, K.L.; Racloz, V.; McElhinney, L.M.; Marston, D.A.; Johnson, N.; Ronsholt, L. Molecular epidemiological study of Arctic rabies virus isolates from Greenland and comparison with isolates from throughout the Arctic and Baltic regions. Virus Res. 2006, 116, 1-10. [CrossRef]

18. Kissi, B.; Tordo, N.; Bourhy, H. Genetic polymorphism in the rabies virus nucleoprotein gene. Virology 1995, 209, 526-537. [CrossRef] [PubMed]

19. Talbi, C.; Holmes, E.C.; de Benedictis, P.; Faye, O.; Gamatie, E.N.D.; Diarra, A.; Elmamy, B.O.; Sow, A.; Adjogoua, E.V.; Sangare, O.; et al. Evolutionary history and dynamics of dog rabies virus in western and central Africa. J. Gen. Virol. 2009, 90, 783-791. [CrossRef]

20. Olarinmoye, A.O.; Kamara, V.; Jomah, N.D.; Olugasa, B.O.; Ishola, O.O.; Kamara, A.; Luka, P.D. Molecular detection of rabies virus strain with $\mathrm{N}$-gene that clustered with China lineage 2 co-circulating with Africa lineages in Monrovia, Liberia: First reported case in Africa. Epidemiol. Infect. 2019, 147, e85. [CrossRef]

21. Sabeta, C.T.; Mansfield, K.L.; McElhiney, L.M.; Fooks, A.R.; Nel, L.H. Molecular epidemiology of rabies in bat-eared foxes (Otocyonmegalotis) in South Africa. Virus Res. 2007, 129, 1-10. [CrossRef]

22. David, D.; Osinubi, M.O.V.; Nok, A.J.; Ogunkoya, A.B.; Umoh, J.U.; Balogun, E.; Yakobson, B.A. Molecular epidemiology of canine rabies isolates from Plateau State Nigeria. In Proceedings of the National Conference/Workshop on Rabies; IDR-ABU: Zaria, Nigeria, 2008; pp. 84-87.

23. Garba, A. Epidemiology of Rabies in Niger State, Nigeria. Ph.D. Thesis, Ahmadu Bello University, Zaria, Nigeria, 2015.

24. Kia, G.S.N.; Huang, Y.; Zhou, M.; Zhou, Z.; Gnanadurai, C.W.; Leysona, C.M.; Umoh, J.U.; Kazeem, H.M.; Ehizibolo, D.O.; Kwaga, J.K.P.; et al. Molecular characterization of a rabies virus isolated from trade dogs in Plateau State, Nigeria. Sokoto J. Vet. Sci. 2018, 16, 54-62. [CrossRef] 
25. Eze, U.U.; Anene, B.M.; Chukwu, C.C.; Ogunkoya, A.B.; George, S.O.; Eze, J.I.; Animoke, P.C.; Nwosuh, C.I. Risk of typical rabies in dog meat-eating human population, in Enugu, Nigeria. Int. J. Public Health Epidemiol. 2015, 4, 107-109.

26. Chigere, N.H. Foreign Missionary Background and Indigenious Evangelization in Igboland: Igboland and the Igbo People of Nigeria; Transaction Publishers: Piscataway, NJ, USA, 2000; p. 17.

27. Dean, D.J.; Abelseth, M.K.; Atanasiu, P. The fluorescent antibody test. In Laboratory Techniques in Rabies, 4th ed.; Meslin, F.-X., Kaplan, M.M., Koprowski, H., Eds.; World Health Organization: Geneva, Switzerland, 1996; pp. 88-95.

28. Heaton, P.R.; Johnstone, P.; McElhinney, L.M.; Cowley, R.; O'Sullivan, E.; Whitby, J.E. Heminested PCR assay for the detection of six genotypes of rabies and rabies related viruses. J. Clin. Microbiol. 1997, 35, 2762-2766. [CrossRef] [PubMed]

29. Markotter, W.; Kuzmin, I.; Rupprecht, C.E.; Randles, J.; Sabeta, C.T.; Wandeler, A.I.; Nel, L.H. Isolation of Lagos bat virus from water mongoose. Emerg. Infect. Dis. 2006, 12, 1913-1918. [CrossRef] [PubMed]

30. Tordo, N.; Poch, O.; Ermine, A.; Keith, G.; Rougeon, F. Walking along the rabies genome: Is the large G-Lintergenic region are mnantgene? Proc. Natl. Acad. Sci. USA 1986, 83, 3914-3918. [CrossRef] [PubMed]

31. Kwok, S.A.; Higuchi, R. Avoiding false positives with PCR. Nature 1989, 339, 237-238. [CrossRef] [PubMed]

32. Hall, T.A. BioEdit: Auser-friendly biological sequence alignment editor and analysis program for Windows 95/98/NT. Nucleic Acid Symp. 1999, 41, 95-98.

33. Thompson, J.D.; Higgins, D.G.; Gibson, T.J. CLUSTALW: Improving the sensitivity of progressive multiple alignment through sequence weighting, position-specific gap penalties and weight matrix choice. Nucleic Acids Res. 1994, 22, 4673-4680. [CrossRef]

34. Kumar, S.; Strecher, G.; Tamura, K. MEGA7: Molecular evolutionary genetic analysis version 7.0 for bigger dataset. Mol. Biol. Evol. 2016, 33, 1870-1874. [CrossRef]

35. Tamura, K.; Dudley, J.; Nei, M.; Kumar, S. MEGA4: Molecular Evolutionary Genetics Analysis (MEGA) software version 4.1. Mol. Biol. Evol. 2007, 24, 1596-1599. [CrossRef]

36. Hills, D.M.; Bull, J.J. An empirical test of bootstrapping as a method for assessing confidence in phylogenetic analysis. Syst. Biol. 1993, 42, 182-192. [CrossRef]

37. Kimura, M. A simple method for estimating evolutionary rate of base substitutions through comparative studies of nucleotide sequences. J. Mol. Evol. 1980, 16, 111-120. [CrossRef]

38. De Benedictis, P.; Sow, A.; Fusaro, A.; Veggiato, C.; Talbi, C.; Kabore, A.; Dundon, W.G.; Bourhy, H.; Capua, I. Phylogenetic analysis of rabies viruses from Burkina Faso, 2007. Zoonoses Public Health 2009, 57, $42-46$. [CrossRef]

39. Ogunkoya, A.B.; Beran, G.W.; Wiktor, T.J. Antigenic analysis of some Nigerian street rabies virus using monoclonal antibodies. Niger. J. 2000, 27, 241-253.

40. Smith, J.S.; Pamela, A.; Yager, P.A.; Bigler, W.J.; Eldert, C.; Hartwig, E.C. Surveillance and epidemiologic mapping of monoclonal antibody-defined rabies variants in Florida. J. Wildl. Dis. 1990, 26, 473-485. [CrossRef] [PubMed]

41. Paez, A.; Nunez, C.; Grarcia, C.; Bushel, J. Molecular epizootics in Columbia: Evidence for human and dog rabies associated with bats. J. Gen. Virol. 2003, 84, 795-802. [CrossRef] [PubMed]

42. Johnson, N.; Letshwenyo, M.; Baipoledi, E.K.; Thebokwe, G.; Fooks, A.R. Molecular epidemiology of rabies in Botswana: A comparism between antibody typing and nucleotide sequence phylogeny. Vet. Microbiol. 2004, 101, 31-38. [CrossRef] [PubMed]

43. Nel, L.H.; Sabeta, C.T.; Von Teichman, B.; Jaftha, J.B.; Rupprecht, C.E.; Bingham, J. Mongoose rabies in southern Africa: Are-evaluation based on molecular epidemiology. Virus Res. 2005, 109, 165-173. [CrossRef]

44. Van Zyl, N.; Markotter, W.; Nel, L.H. Evolutionary history of African Mongoose rabies virus. Virus Res. 2010, 150, 93-102. [CrossRef]

45. Wiktor, T.J.; Marcfalan, R.I.; Foggin, C.M.; Koprowski, H. Antigenic analysis of rabies and Mokola virus from Zimbab we using monoclonal antibodies. Dev. Biol. Stand. 1984, 57, 199-211.

46. Sabo, G.; Umoh, J.U.; Sackey, A.K.B.; Ahamd, A.; Okolocha, E.C. The role of dog trade in the epidemiology of rabies: A review. Vet. Clin. Pract. Bull. 2008, 1, 63-72. 
47. Fevre, E.M.; Kaboyo, R.W.; Persson, V.; Edelsten, M.; Coleman, P.G.; Cleaveland, S. The epidemiology of animal bite injuries in Uganda and projections of the burden of rabies. Trop. Med. Int. Health 2005, 10, 790-798. [CrossRef]

48. Bourhy, H.; Reynes, J.M.; Dunham, E.J.; Dacheux, L.; Larrous, F.; Huong, V.T.Q.; Xu, G.; Yan, J.; Miranda, M.E.G.; Holmes, E.C. The origin and phylogeography of dog rabies virus. J. Gen. Virol. 2008, 89, 2673-2681. [CrossRef]

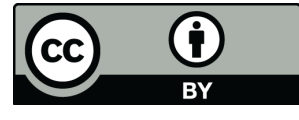

(C) 2020 by the authors. Licensee MDPI, Basel, Switzerland. This article is an open access article distributed under the terms and conditions of the Creative Commons Attribution (CC BY) license (http://creativecommons.org/licenses/by/4.0/). 